\title{
Development of Neurons in the Ectostriatum of Normal and Monocularly Deprived Zebra Finches: A Quantitative Golgi Study
}

\author{
KATHRIN HERRMANN AND HANS-JOACHIM BISCHOF \\ Universität Bielefeld, Fakultät für Biologie, 4800 Bielefeld 1, \\ Federal Republic of Germany
}

\begin{abstract}
The postnatal development of the main neuron type in the ectostriatum, the telencephalic station of the tectofugal pathway, was followed in normally reared and monocularly deprived zebra finches by using the Golgi method. Three parameters were investigated: dendritic field radius, branching index, and spine density. The results show that all three exhibit the same developmental trend-namely, an increase from day 5 until day 20 , followed by a subsequent reduction until adulthood ( $>100$ days). Monocular deprivation from birth until day 20,40 , or at least 100 does not seem to interfere with the development of the dendritic field radius or branching index. Clear changes in spine density result from depriving the birds for at least 40 days. In these birds, neurons in the deprived hemisphere bear significantly fewer spines than those in the nondeprived hemisphere, which is mainly due to a lack of normally occurring spine reduction in the nondeprived hemisphere rather than to spine reduction in the deprived hemisphere.
\end{abstract}

Key words: ontogeny, spines, visual deprivation, birds, overshoot

An abundant literature has accumulated addressing the nature-nurture dichotomy, i.e., the interaction of genetic and epigenetic factors influencing the early developing nervous system. Important contributions came from experiments on the visual system of mammals, perhaps mainly because of the relative ease of controlling the environmental factor by deprivation. Many researchers have confirmed and extended Hubel and Wiesel's results (e.g., Hubel and Wiesel, '70; Wiesel and Hubel, '63a,b, '65) of monocular and binocular deprivation, and it is now widely accepted that early visual experience has major effects on the structural and physiological development of the geniculocortical and extrageniculocortical pathway (for review see Blakemore, '78; Fregnac and Imbert, '84; Movshon and Van Sluyters, '81; Sherman and Spear, '82).

Besides the well-studied deprivation-induced changes in cell size in the lateral geniculate nucleus (LGN) of various mammals (e.g., Casagrande and Joseph, '80; Chow and Spear, '74; Headon et al., '85; Hickey et al., '77; Guillery, '72; Sherman and Wilson, '75), the altered pre- and postsynaptic structure of the visual cortex has been investigated in many Golgi and EM studies. At the ultrastructural level changes in synaptic density (Cragg, '75a; Fifkova, '70; Tie- man, '84; Turlejki and Kossut, '85; Winfield, '83), in the number of vesicles (Garey and Pettigrew, '74; Vrensen and de Groot, '75), and in presynaptic terminal size (Fifkova, '70; Tieman, '84) as a result of dark rearing or monocular deprivation have been reported in cats, rats, and rabbits (but not in monkeys: O'Kusky and Colonnier, '85). When using the Golgi method a decreased spine density was reported in the visual cortex of monocularly deprived rats (Fifkova, '68; Rothblat and Schwarz, '79), dark-reared mice (Ruiz-Marcos and Valverde, '69; Valverde, '67), and darkreared rats (Winckelmann et al., '76). Changes in the size (Freire, '78) and shape (Globus and Scheibel, '67) of cortical dendritic spines in mice and rabbits have also been documented.

In spite of the large literature for mammals, data on the effects of monocular occlusion in birds are sparse. This is particularly remarkable as the visual system of birds, with its completely crossed optic nerve, provides an excellent model for such studies.

\section{Accepted April 23, 1988.}

Kathrin Herrmann's present address is Department of Psychology, University of California, Los Angeles, CA 90024. 
Most of the effects of early unilateral occlusion in mammals have been attributed to the unbalanced binocular competition. Most studies on birds deal with deprivationinduced changes in the visual wulst (Bagnoli et al., '82, '83; Burkhalter et al., '82; Pettigrew and Konishi, '76), which is probably homologous to the visual cortex in mammals (Nauta and Karten, '70). In this pathway binocularity is achieved by recrossing of thalamotelencephalic fibers. How ever, in the second ascending visual pathway, the tectofugal system (comparable to the extrageniculocortical pathway), monocular deprivation creates similar anatomical abnormalities to those described in the geniculocortical pathway (Herrmann and Bischof, '86b,c; Nixdorf and Bischof, '87), although many studies have claimed all stations of this projection-tectum opticum, nucleus rotundus, and ectostriatum - to be mainly monocularly driven (Benowitz and Karten, '76; Revzin and Karten, '66/67). The small tectotectal as well as the tectocontralateral rotundus, wulstectostriatum, and wulst tectum fibers have been considered to be insignificant (Bagnoli et al., '77; Benowitz and Karten, '76; Hunt and Künzle, '76; Ritchie and Cohen, '77), as no binocular neurons have been found in any of these areas so far.

However, recent electrophysiological and anatomical evidence from our lab (Engelage and Bischof, '88; Niemann et al., '87) suggests that in zebra finches there is a high degree of interaction in the nucleus rotundus and the ectostriatum. This is supported by the cell size and ultrastructural changes found after monocular deprivation in these areas (Herrmann and Bischof, '86b,c; Nixdorf and Bischof, '87), which can only be interpreted by an exchange of information from left and right eye. Therefore, the morphological changes induced by unilateral occlusion in zebra finches seem to be comparable to those in the geniculocortical pathway, although these regions are nonhomologous.

This study investigates the effects of early monocular deprivation on dendritic parameters (e.g., spine density, dendritic length, and branching index) of neurons in the ectostriatum of zebra finches, the telencephalic station of the tectofugal pathway. In addition to comparisons between the deprived and nondeprived hemisphere in the monocularly deprived birds we also compared these birds with those which had been normally reared, because monocular deprivation interferes with the neuronal development, and transfer of information can occur between the two hemispheres.

\section{MATERIALS AND METHODS Subjects}

A total of 29 normal and monocularly deprived zebra finches (Taeniopygia guttata castanotis) of both sexes were used for this study. All birds were taken from the institute's stock. Normal development was studied in the following age groups: 5 days $(n=3), 10$ days $(n=5), 20$ days $(n=5)$, 40 days $(n=3)$, and $\geqslant 100$ days $=$ adult $(n=4)$. Nine birds were monocularly deprived from birth until death at day $20(n=4), 40(n=3)$ or as adults $(n=2)$.

The birds were deprived by gluing a dark plastic cap over one of the eyes (left or right) with Dow Corning medical adhesive. Deprivation began at 1 or 2 days posthatching, at a time when the birds' eyes are still closed (zebra finches open their eyes at the age of 5 days).

\section{Processing of the tissue}

The birds were deeply anesthetized with $0.03 \mathrm{ml}$ Nembutal and perfused via the left ventricle with $0.9 \% \mathrm{NaCl}$ followed by $10 \%$ formalin in $0.9 \% \mathrm{NaCl}$. After postfixing for at least 1 week in this second solution, the brains were removed from the skull. After additional postfixing the brains were processed in toto by using a modification of the Golgi Bubenaite method (Romeis, '68): The brains were placed in a solution of $2.5 \%$ potassium dichromate and kept in the dark for 48 hours at $34^{\circ} \mathrm{C}$. They were then washed three times in a $2 \%$ solution of silver nitrate and stored in the dark for 3 (the 5- and 10-day-old birds) or 4 days (animals older than 10 days) in a fresh $2 \% \mathrm{AgNO}_{3}$ solution. Then the brains were transferred to a 1:1 mixture of $80 \%$ ethanol and glycerol overnight. On the following day 90120- $\mu$ m-thick serial coronal sections were cut with a microtome. The sections were dehydrated in methylsalicylate and $100 \%$ ethanol, cleared in xylene, mounted, and coverslipped with DePeX (Serva).

In all deprived birds the data analysis was done "blind"; i.e., the right hemisphere was marked with a needle, irrespective of whether it was the deprived or the nondeprived hemisphere. The code was not broken until the end of all measurements.

\section{Data analysis}

The neurons were analyzed from drawings made with the help of a drawing tube attached to a Zeiss microscope at a magnification of $\times 1,250$ under oil. For drawing, the cells had to fulfill the following criteria: 1) good impregnation of all dendrites with continuous staining over their full length, 2) all dendrites of one neuron in one section (to avoid following up dendrites in serial sections), and 3) neurons clearly in the ectostriatal core region (to avoid having to distinguish between "belt" and "core" regions).

By this procedure we obtained 435 drawings (normal birds): 5 days $(n=37), 10$ days $(n=48), 20$ days $(n=42)$, 40 days $(n=27) \geqslant 100$ days $(n=85)$; deprived birds: 20 days $(n=84), 40$ days $(n=68)$, and $\geqslant 100$ days $(n=44)$.

Radius of the dendritic field. The size of the dendritic field was determined by measuring the distance between the center of the soma and the tip of the longest dendrite with the help of an overlay with concentric rings superimposed over the soma center. It should be emphasized, however, that the radius of the dendritic field is an underestimation of the three-dimensional spread of the dendritic field.

Branching index. For the quantitative evaluation of the branching frequency the number of dendritic tree endings (= free dendritic tips) was divided by the number of primary dendrites per neuron to obtain the number of dendritic tips per primary dendrite. We used this method to correct for neurons that had three, four, or five primary dendrites but nevertheless belonged to the same neuron type (Figs. 1, 4a).

Spine counts. Spine counts were expressed as frequency per $10-\mu \mathrm{m}$ linear dendritic length. The dendritic elements were only selected for spine density measurements if they were absolutely parallel to the plane of section and were longer than $10 \mu \mathrm{m}$.

Every process protruding from the dendritic shaft was counted as a spine, irrespective of its morphological shape (stubby or pedunculated, with or without a terminal expansion) provided it only appeared to be in direct continuity with the dendritic shaft. Double spines, i.e., spines with two heads or endings, were counted as two spines (Schüz, '81), but they were not frequent (about one to three per neuron).

The absolutely straight dendrites were marked during drawing; their length was calculated with a Graphics Tab- 


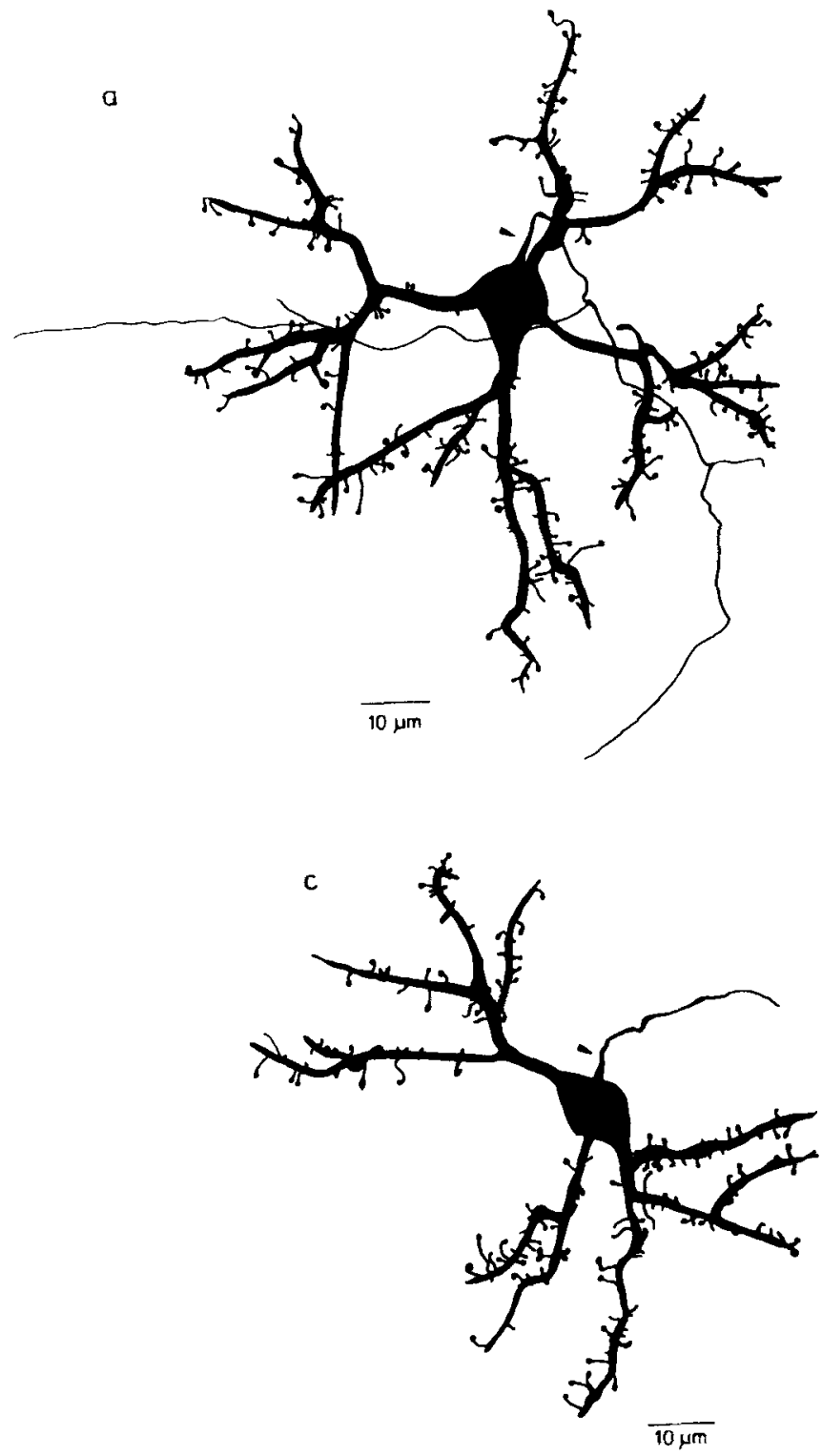

Fig 1. Camera lucida drawings of four typical Golgi-impregnated type I neurons of the ectostriatum of adult zebra finches. The axons are indicated let; and the corresponding number of spines and their exact location on the dendrite ( $p, s, m$ and $t$, see below) were stored by means of an HP-computer linked to the Graphics Tablet. We designed a program to calculate the number of spines per $10 \mu \mathrm{m}$.

The dendritic elements were classified according to their position in the dendritic tree as primary (p), secondary (s), middle $(\mathrm{m})$, and terminal $(\mathrm{t})$ segments; this classification has proved to be useful in the analysis of birds' telencephalic neurons (Rausch and Scheich, '82; Wallhäusser and Scheich, '87). No attempt was made to correct for hidden spines (Feldman and Peters, '79), so our counts underestimate the actual number. by an arrowhead. The neurons of this main cell type are characterized by a

small soma and three (b,c) or four (a,d) primary dendrites.
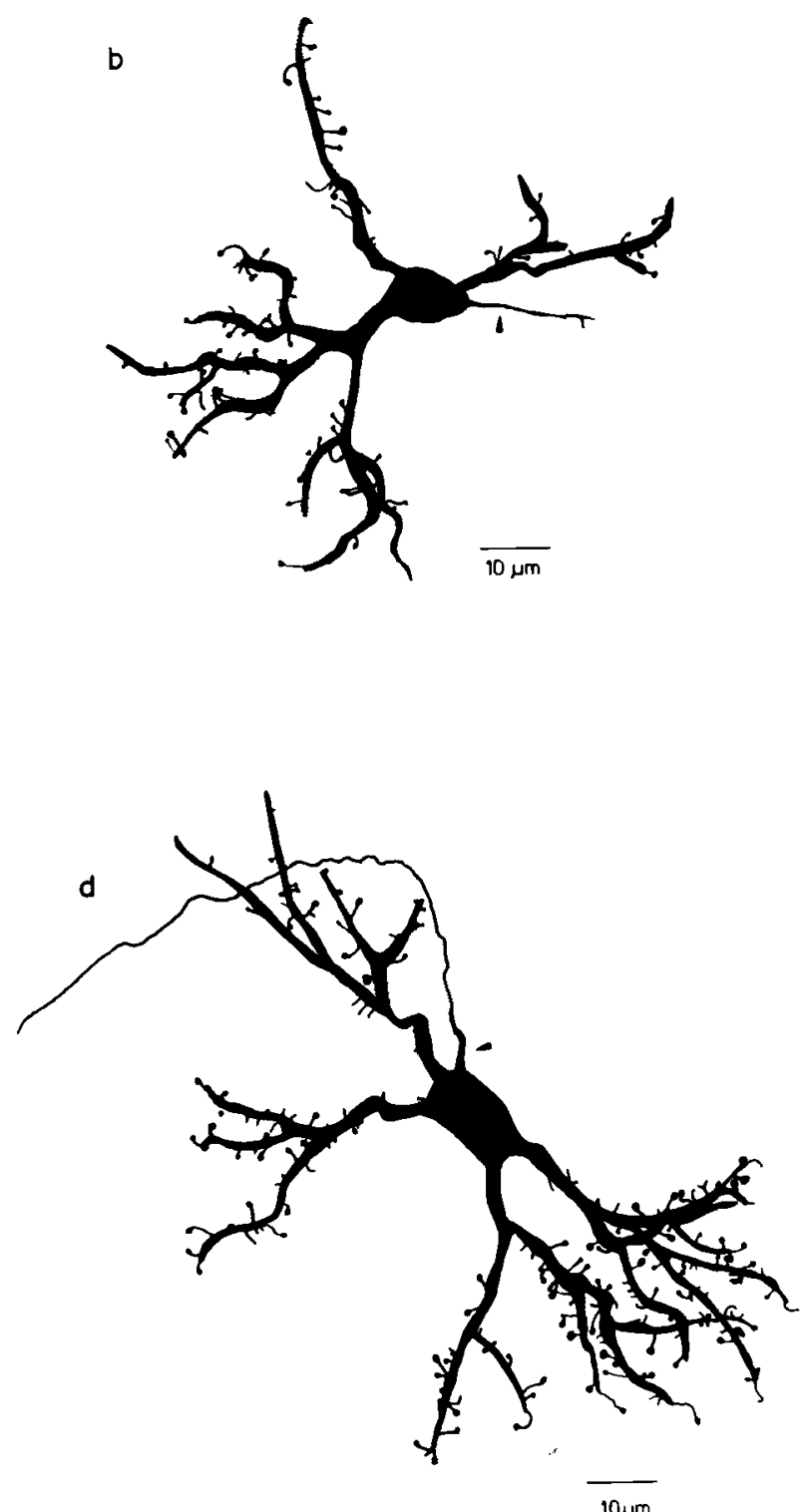

\section{Statistics}

For the analysis of the branching frequency and the radius of the dendritic field, a mean value was calculated for each animal. These means were used to determine the mean value in each age group (three to five birds). The differences were tested with a Student's t-test.

For the spine measurements we pooled all the values of one age group and one hemisphere, although it is clear that the observations for each animal were not independent. However, because of the small sample size and the fact that the dendritic elements came from a differing number of neurons, we decided to treat each spine count $/ 10 \mu \mathrm{m}$ as one observation. These results did not differ significantly from those obtained in separate measurements for each individ- 

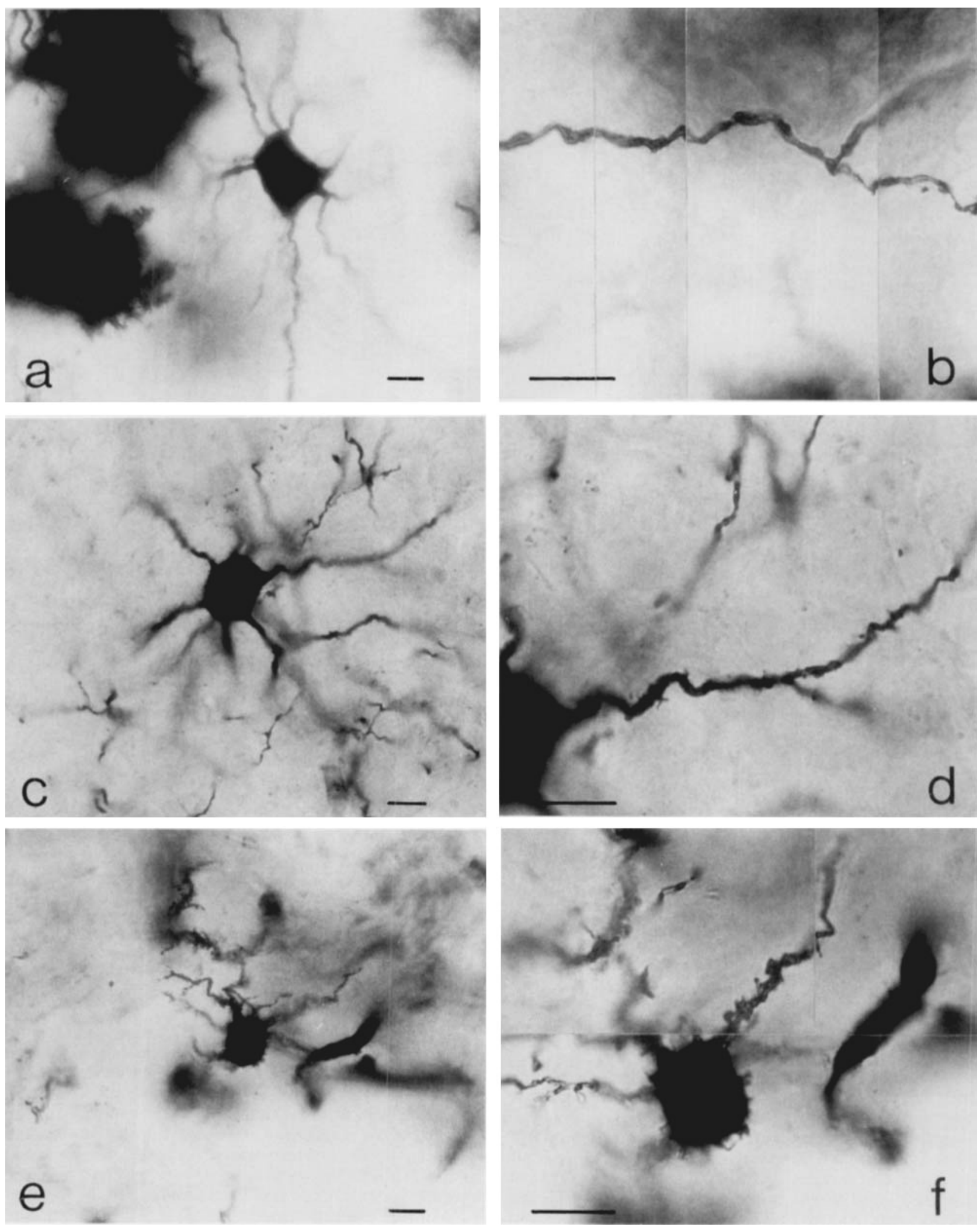

Fig. 2. Photographs of the ectostriatal type II neurons of different ages. a,b: Adult. c,d: twenty days. e, f: ten days. This rarely impregnated neuron

dendrites $(a, c, e)$. The dendrites bear only very few, usually small, unpedunculated spines at all age groups $(b, d, f)$. Note the frequent somatic spines in 10-day-old birds. Bar is $10 \mu \mathrm{m}$. 


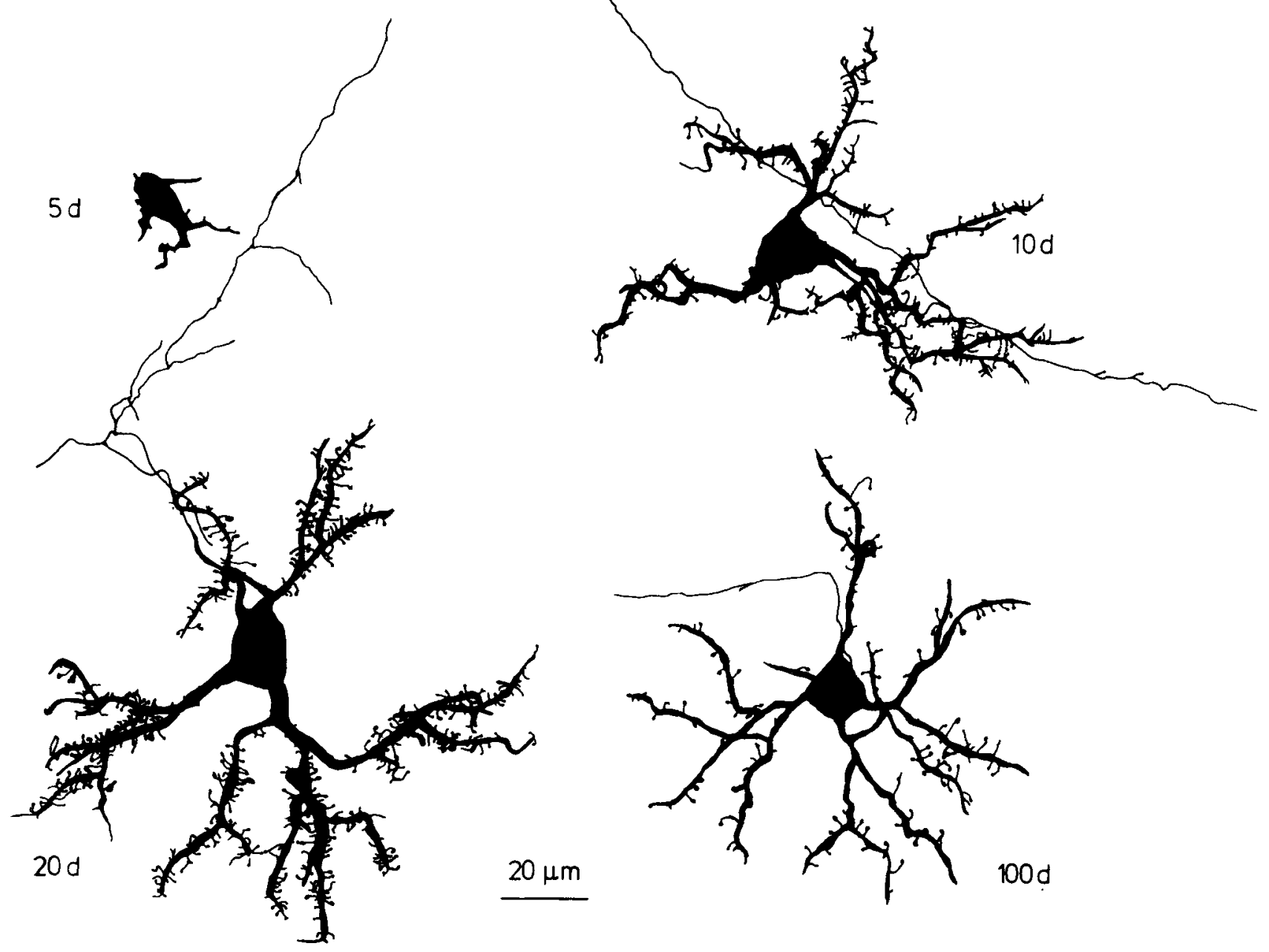

Fig. 3. Typical stages of maturation of the ectostriatal type I neuron at 5, 10, 20, and 100 days. For further explanation see text.

ual bird. Differences between the age groups and differences between hemispheres (deprived/nondeprived) were tested for mean value variations of the median with the nonparametric U-test.

\section{RESULTS \\ Qualitative observations}

Figures 1 and 2 show the two types of Golgi-impregnated neurons in the ectostriatum of adult zebra finches. The main neuron type (Fig. 1), which has also been described in the Japanese quail (Watanabe et al., '85) has a soma diameter of about $15 \mu \mathrm{m}$. Several (three to five) dendrites emanate from the soma and arborize one to four times. They are oriented radially; only dendrites near the LMD (lamina medullaris dorsalis) or the FA (fasciculus archistriatalis), the medial and ventral borders of the ectostriatum, are oriented parallel to these fiber systems. Figure $4 \mathrm{a}$ shows one neuron with radially oriented dendrites and another lying adjacent to the ventral border of the ectostriatum. The dendrites extend about $55 \mu \mathrm{m}$ from the soma but never leave the ectostriatum to enter adjacent structures such as the PA (paleostriatum augmentatum). The dendrites bear spines of different shape. In some Golgi preparations axons could be traced for more than $100 \mu \mathrm{m}$. They arborize sometimes, and single axon collaterals could be traced into the paleostriatum or neostriatum.

The second neuron type (Fig. 2) was impregnated very rarely. Soma (diameter $20 \mu \mathrm{m}$ ) and dendrites (length more than $100 \mu \mathrm{m}$ ) are much larger than in neuron type I and the number of primary dendrites ( 8 to 12$)$, which bear only very few spines in adult birds (Fig. 2), is twice as high. The axons were not impregnated over long distances. Because of the small sample size of the second neuron type (a total of only 11 neurons in all brains examined), we only used the type I neurons for the quantitative analysis of development and deprivation effects. However, also in this neuron type II a reduction in the number of dendritic spines can be observed (Fig. 2). Interestingly, in 10-day-old birds some somatic spines can also be seen, which are absent in adult animals.

In 5-day-old zebra finches the ectostriatal type I neurons consist of typically undifferentiated cells with a small soma (Figs. 3, 4b). The dendrites are irregularly thickened and 

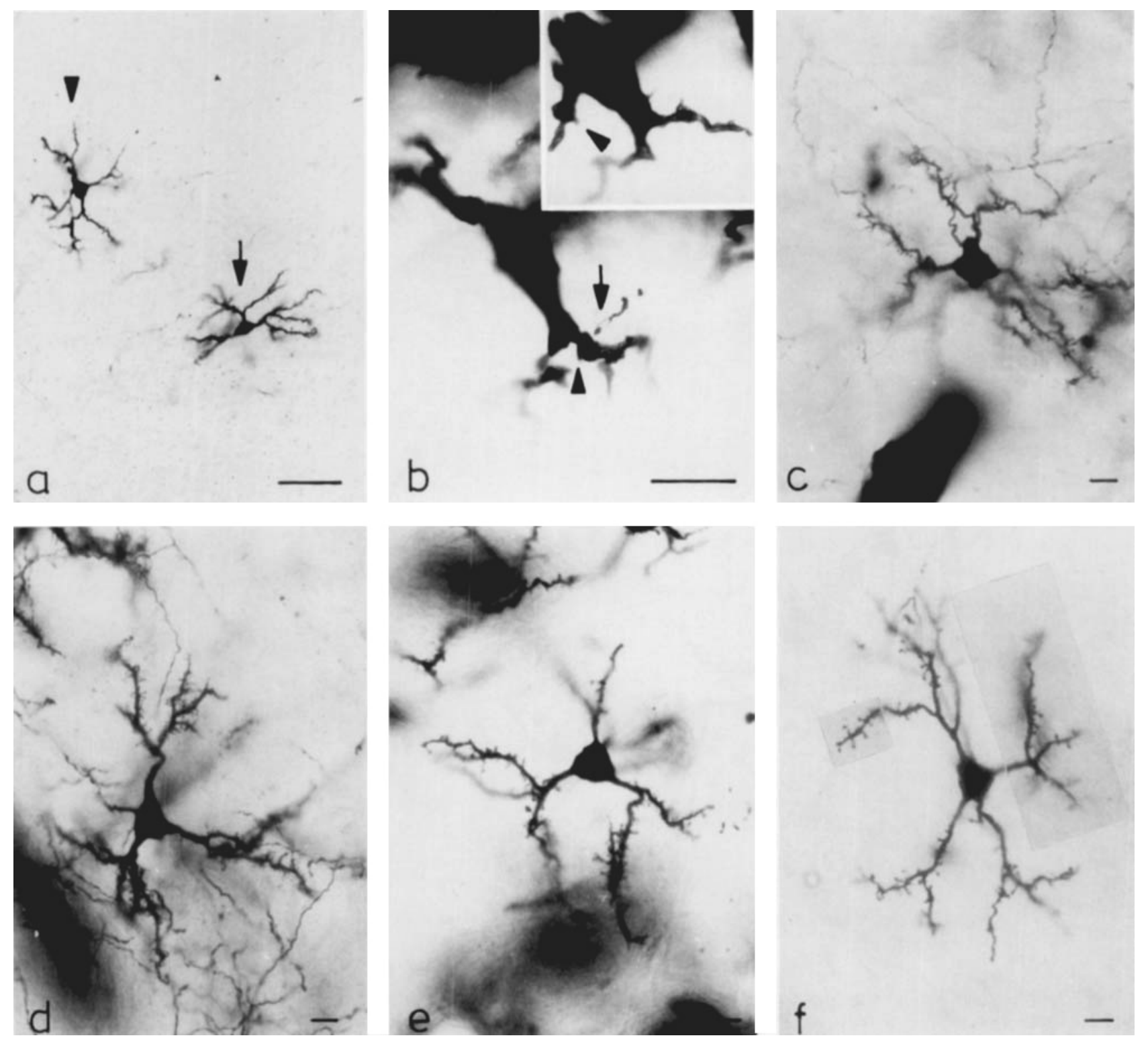

Fig. 4. Photomicrographs of ectostriatal type I neurons in zebra finches of different ages. a: Two neurons (normally reared 20-day-old male) with different dendritic orientation. The arrowhead marks a neuron with four radially oriented dendrites; the arrow marks a tripolar neuron with dendrites oriented parallel to the ventral border of the ectostriatum. b: Two neurons from 5-day-old zebra finches; arrowheads mark growth buds (swell-

ings along the dendrites) and growth cones (terminal swellings); one filopodium is marked by an arrow. c: Neuron of a 10-day-old zebra finch. At this age the typical cell form is already achieved. $d$ : Twenty-day-old bird: the dendrites bear more spines than at earlier or later age groups. e: Forty-dayold bird. f: Neuron of an adult zebra finch. Bar is $50 \mu \mathrm{m}$ in a and $10 \mu \mathrm{m}$ in old bir.

bear growth cones and growth buds, which are often sites of origin for filopodia (Fig. $4 \mathrm{~b}$ ). The rare spiny processes are thin and lack peduncular endings. Between days 5 and 10 ectostriatal neurons exhibit a very rapid growth (Figs. 3 , $4 c)$. The soma diameter increases and the dendrites grow massively and bifurcate. All dendritic parts are covered with numerous thin spines, which sometimes already have bulbous terminals. The soma contours are irregular in shape, but in contrast to 10-day-old type II neurons, somatic spines are hardly ever found (compare Figs. 2c and 4c). Between day 10 and 20 ectostriatal neurons increase further in soma size, dendritic length, and branching frequency. The number of dendritic spines increases dramatically and gives the dendrites the appearance of barbed wire (Figs. 3, 4d). After day 20 a reduction in soma size, dendrites, and the number of spines can be detected even without quantitative analysis (Figs. 3, 4e,f).

\section{Quantitative neuronal development}

Radius of the dendritic field. The mean dendritic field radius is shown as a function of postnatal age (Fig. 5, Table 1). Between day 5 and 10 the dendritic field radius grow's significantly more than twofold and reaches a mean value of $55.10 \mu \mathrm{m}(P<.001)$. The radius increases again by $29 \%$ from day 10 to day 20. After this age the dendritic field radius of ectostriatal neurons decreases significantly by 


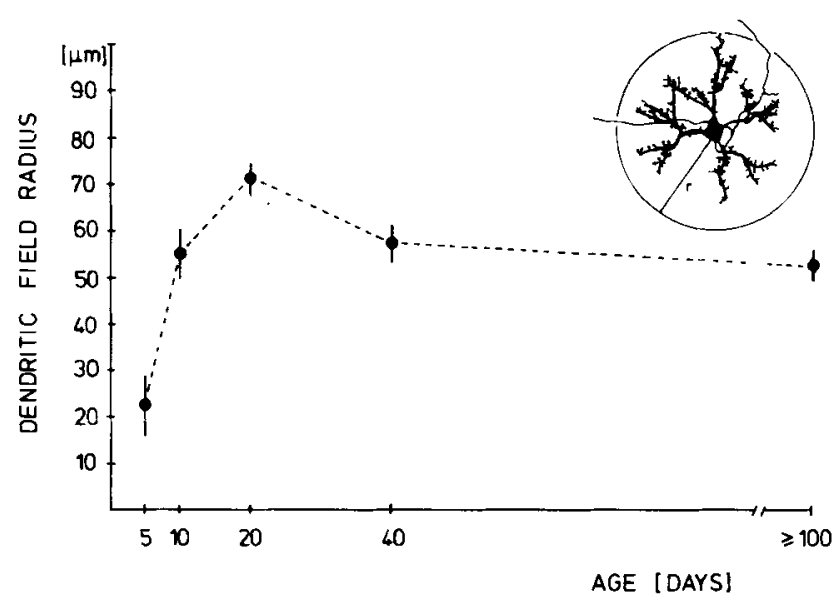

Fig. 5. Development of the dendritic field radius from day 5 until adulthood ( $\geqslant 100$ days). The data show the mean \pm S.E.

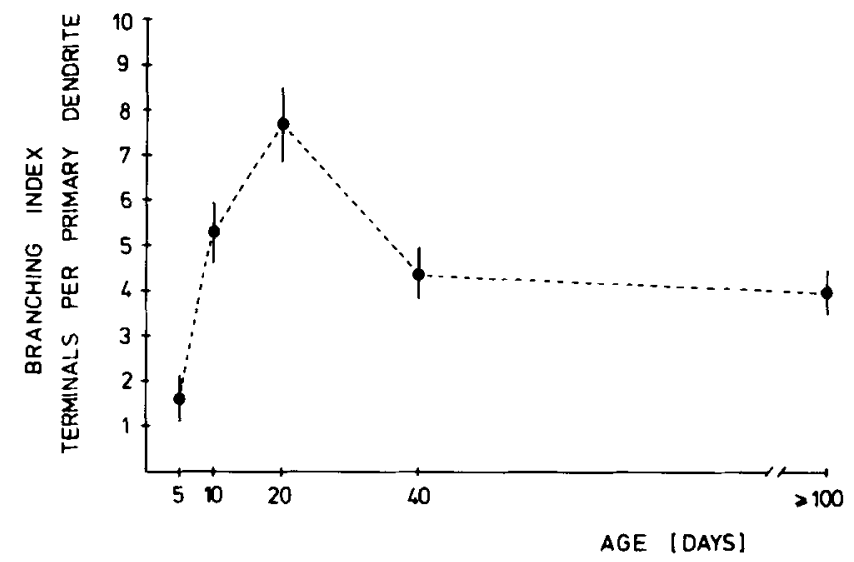

Fig. 6. Development of the branching index from postnatal day 5 until adulthood. The data show the mean \pm S.E.

$19.5 \%(\mathrm{t}=5.26, \mathrm{DF}=6, P<.009)$, whereas further decline $(8 \%)$ in the dendritic field radius after day 40 is only weakly significant $(\mathrm{t}=1.73, \mathrm{DF}=5, P<.073)$.

Branching index. The estimation of the branching index is the number of terminals per primary dendrite and is plotted in Figure 6 as a function of postnatal age (see also Table 1). Between day 5 and 10 the branching index of ectostriatal neurons triples and the further increase by $44 \%$ in the following 10 days is also highly significant $(P<$ .0001 ). Between days 20 and 40 , however, the number of free dendritic terminals per primary dendrite decreases significantly $(\mathrm{t}=5.68, \mathrm{DF}=6, P<.006)$ by about $50 \%$. The further slight reduction in branching index between day 40 and adulthood is not statistically significant. It is remarkable that the branching index of ectostriatal neurons of adult zebra finches lies below that of 10-day-old birds.

Dendritic spines. Spine counts on ectostriatal neurons are shown in Figure 7 as a function of postnatal age (and see Table 2). The spine frequency varies systematically with distance from the soma; i.e., usually the spine density is low at primary dendrites and highest at middle or terminal dendritic segments. However, with the exception of

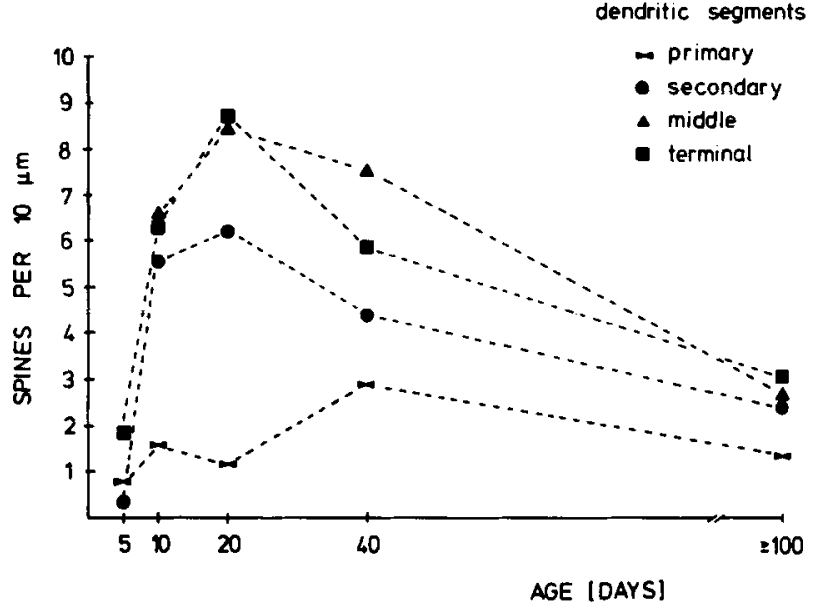

Fig. 7. Ontogenetic changes in spine density on the different dendritic segments (primary, secondary, middle, and terminal) from postnatal day 5 until adulthood. Median values.

the primary dendrites, the ontogenetic changes in the number of spines per unit length of dendrite are similar along all segments.

Primary segments. In primary dendritic segments the number of dendritic spines doubles between days 5 and 10 $(\mathrm{Z}=2.37, P<.025)$ and does not change significantly in the following 10 days. Between days 20 and 40 , however, the number of dendritic spines increases significantly $(\mathrm{Z}=$ $2.605, P<.025$ ), and after day 40 the spine density is drastically reduced $(Z=3.47, P<.001)$.

Secondary segments. On secondary dendrites the number of spines increases dramatically between days 5 and $10(\mathrm{Z}=3.12, P<.005)$, followed by another $12 \%$ increase in the next 10 days, and declines between days 20 and 40 by $29 \%(\mathrm{Z}=2.05, P<.05)$. After day 40 there is a further decline of $45.6 \%$ to the adult value, which lies $61.6 \%$ below the maximum value at day 20 .

Middle segments. In the ectostriatum of 5-day-old zebra finches there are no "middle" dendritic segments of these undifferentiated neurons (see Figs. 3, 4b). Between days 10 and 20 spine density increases significantly $(\mathrm{Z}=2.93, P$ $<.005$ ) and declines slightly in the following 20 days. After day 40 the spine density is drastically reduced $(\mathrm{Z}=$ $4.15, P<.001$ ). Thus, between days 20 and 100 the mean spine density is reduced by $68 \%$.

Terminal segments. A similar result can be obtained for terminal dendritic branches: Spine density increases sig. nificantly from day 5 until day 20 (5: 10-day-Z $=8.37, P$ $<.001,10: 20$-day $-\mathrm{Z}=8.07, P<.001)$ and decreases significantly from day 20 to day $40(\mathrm{Z}=7.06, \mathrm{P}<.001)$. The graph in Figure 7 shows that there is a further $47 \%$ reduction from day 40 until adulthood $(\mathrm{Z}=9.31, P<.001)$.

While no attempt was made to quantify morphological diversity in spine shape, qualitative observations indicate that dendritic spine shape changes quite dramatically with age (Fig. 8). Dendritic spines grow in length and thickness between day 10 and day 20 . After day 20 further morphological differentiation leads to the formation of big, bulbous spine heads.

Taken together, spine density, dendritic field radius, and branching index all show the same developmental pattern: there is an increase until day 20 and a subsequent reduction to adult values. 

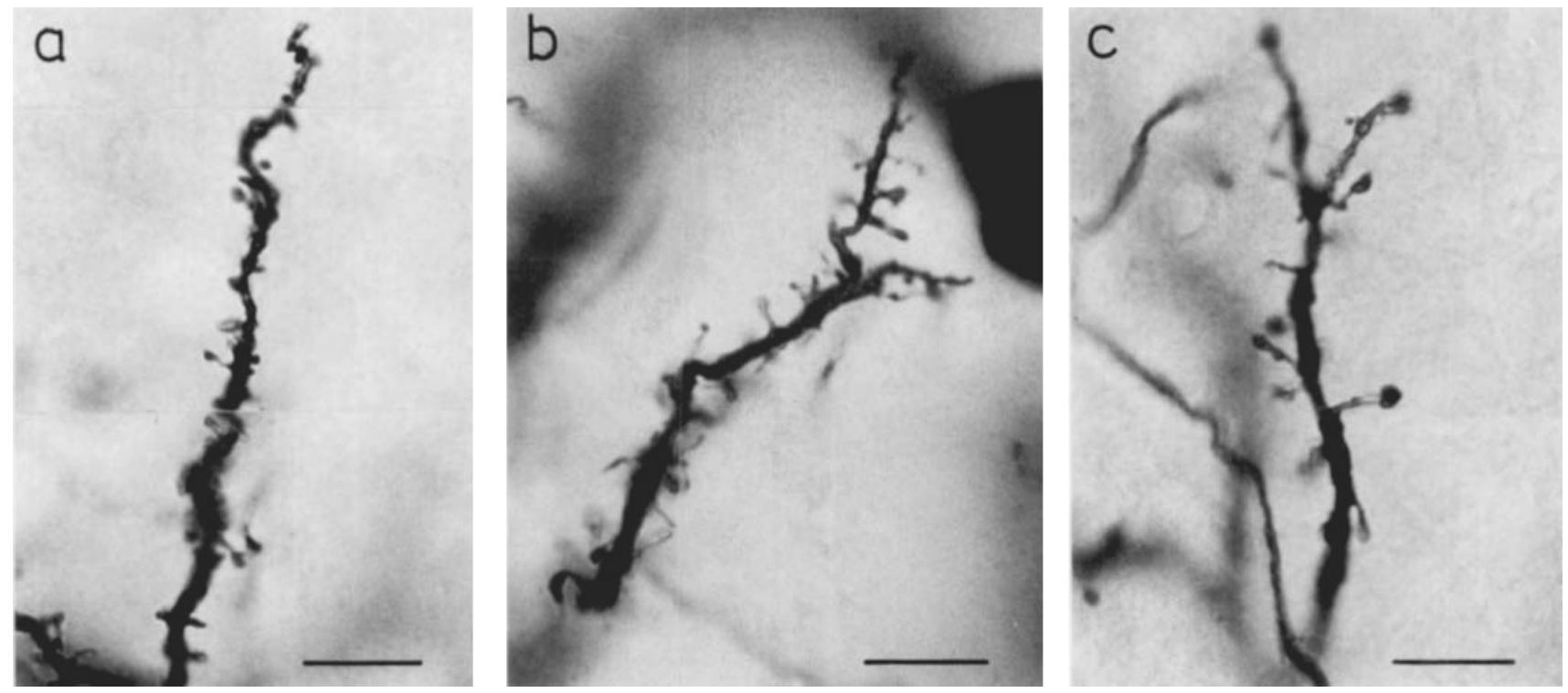

Fig. 8. Dendritic spines in the zebra finch ectostriatum of different ages. a: Ten days: dendritic spines are still very small spicules; many protrusions lack the typical bulbous spine heads. b: Twenty days: the size and number of dendritic spines have drastically increased. (Many spines are not in

focus.) c: Adult: the number of dendritic spines is reduced by about $50 \%$ compared to neurons of 20 -day-old birds. The photo shows a variety of shapes and sizes of spines. Note that many spines are clearly mushroom shaped. Bar is $10 \mu \mathrm{m}$.

TABLE 1. Mean Dendritic Field Radius (a.) and Branching Index (b.) \pm S.E. of Ectostriatal Type I Neurons During Postnatal Development ( $\mathrm{n}=$ number of neurons)

\begin{tabular}{lcccc} 
& \multicolumn{2}{c}{ During Postnatal Development $(\mathrm{n}=$ number of neurons) } \\
\hline Age (days) & $\begin{array}{c}\text { a. Dendritic field } \\
\text { radius }(\mu \mathrm{m})\end{array}$ & $\mathrm{n}$ & $\begin{array}{c}\text { b. Branching } \\
\text { index }\end{array}$ & $\mathrm{n}$ \\
\hline 5 & $22.87 \pm 6.43$ & 37 & $1.61 \pm 0.54$ & 31 \\
10 & $55.10 \pm 5.58$ & 48 & $5.33 \pm 0.69$ & 72 \\
20 & $71.33 \pm 3.53$ & 42 & $7.68 \pm 0.88$ & 38 \\
40 & $57.41 \pm 3.79$ & 27 & $4.44 \pm 0.52$ & 25 \\
$\geqslant 100$ & $52.51 \pm 3.55$ & 85 & $3.98 \pm 0.57$ & 76 \\
\hline
\end{tabular}

TABLE 2. Median Number of Spines \pm S.E. on Different Dendritic Segments (primary, secondary, middle, terminal) of Ectostriatal Neurons at the Ages (days) indicated $(\mathrm{n}=$ number of neurons)

\begin{tabular}{|c|c|c|c|c|c|c|c|c|}
\hline \multirow[b]{2}{*}{ Age } & \multicolumn{8}{|c|}{ Spines per $10 \mu \mathrm{m}$} \\
\hline & Primary & $\mathrm{n}$ & Secondary & $\mathrm{n}$ & Middle & $\mathrm{n}$ & Terminal & $\mathrm{n}$ \\
\hline 5 & $0.74 \pm 1.07$ & 16 & $0.35 \pm 0.70$ & 4 & & & $2.20 \pm 3.71$ & 32 \\
\hline 10 & $1.58 \pm 1.34$ & 34 & $5.55 \pm 3.41$ & 40 & $6.62 \pm 3.03$ & 38 & $6.29 \pm 2.81$ & 190 \\
\hline 20 & $1.16 \pm 1.22$ & 42 & $6.22 \pm 3.51$ & 51 & $8.46 \pm 3.25$ & 83 & $8.71 \pm 2.69$ & 179 \\
\hline 40 & $2.90 \pm 2.61$ & 19 & $4.39 \pm 1.86$ & 19 & $7.56 \pm 1.52$ & 9 & $5.89 \pm 2.10$ & 69 \\
\hline$\geqslant 100$ & $0.70 \pm 0.90$ & 69 & $2.39 \pm 1.85$ & 67 & $2.71 \pm 1.43$ & 20 & $3.10 \pm 1.34$ & 221 \\
\hline
\end{tabular}

\section{Monocular deprivation}

Dendritic field radius. Monocular deprivation does not seem to interfere with the normal development and had no major effect on the dendritic field radius of ectostriatal neurons. After 20 days of monocular deprivation the dendritic field radius of neurons that receive their main input from the deprived eye does not differ from that of cells in the corresponding nondeprived hemisphere. However, the nondeprived hemisphere shows a significantly (7.9\%) smaller radius $(\mathrm{t}=2.03, \mathrm{DF}=7, P<.041$ ) than that of the cells in normally reared birds.

After 40 days of monocular occlusion no interhemispheric asymmetry in dendritic field radius can be observed and there is no difference between these birds and those raised normally. Long-term deprivation until adulthood does not lead to any measurable abnormalities in the dendritic field size: the values of deprived, nondeprived, and normal ectostriatal neurons do not differ statistically (Table 3, Fig. 9).

Branching index. Monocular deprivation for the first 20 days has no effect on the branching index-i.e., the number of free dendritic terminals per primary dendrite (Fig. 9, Table 3)-and the reduction in the number of terminals seen in normally reared zebra finches after day 20 is also paralleled by the development in deprived birds. No statistically significant differences between deprived, nondeprived, or "normal" ectostriatal neurons were found. Longterm deprivation does not lead to any changes in branching index. 


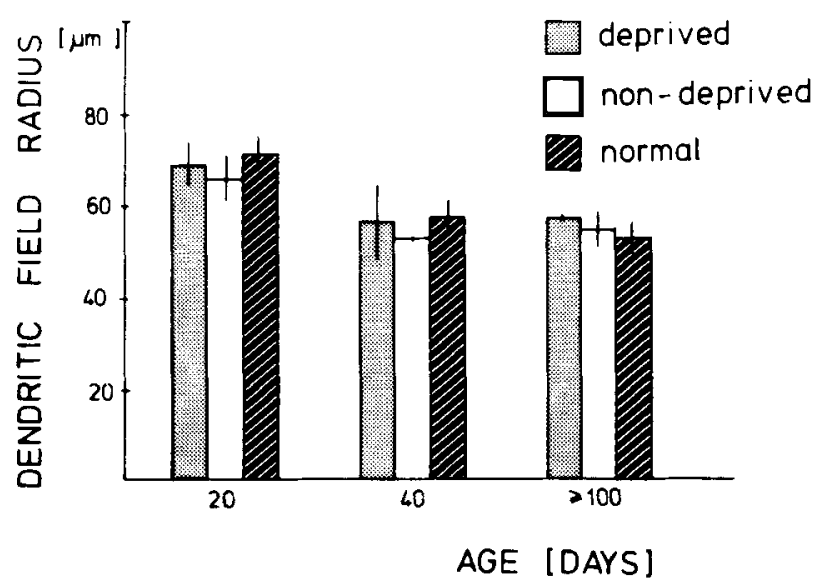

deprived

non-deprived

normal
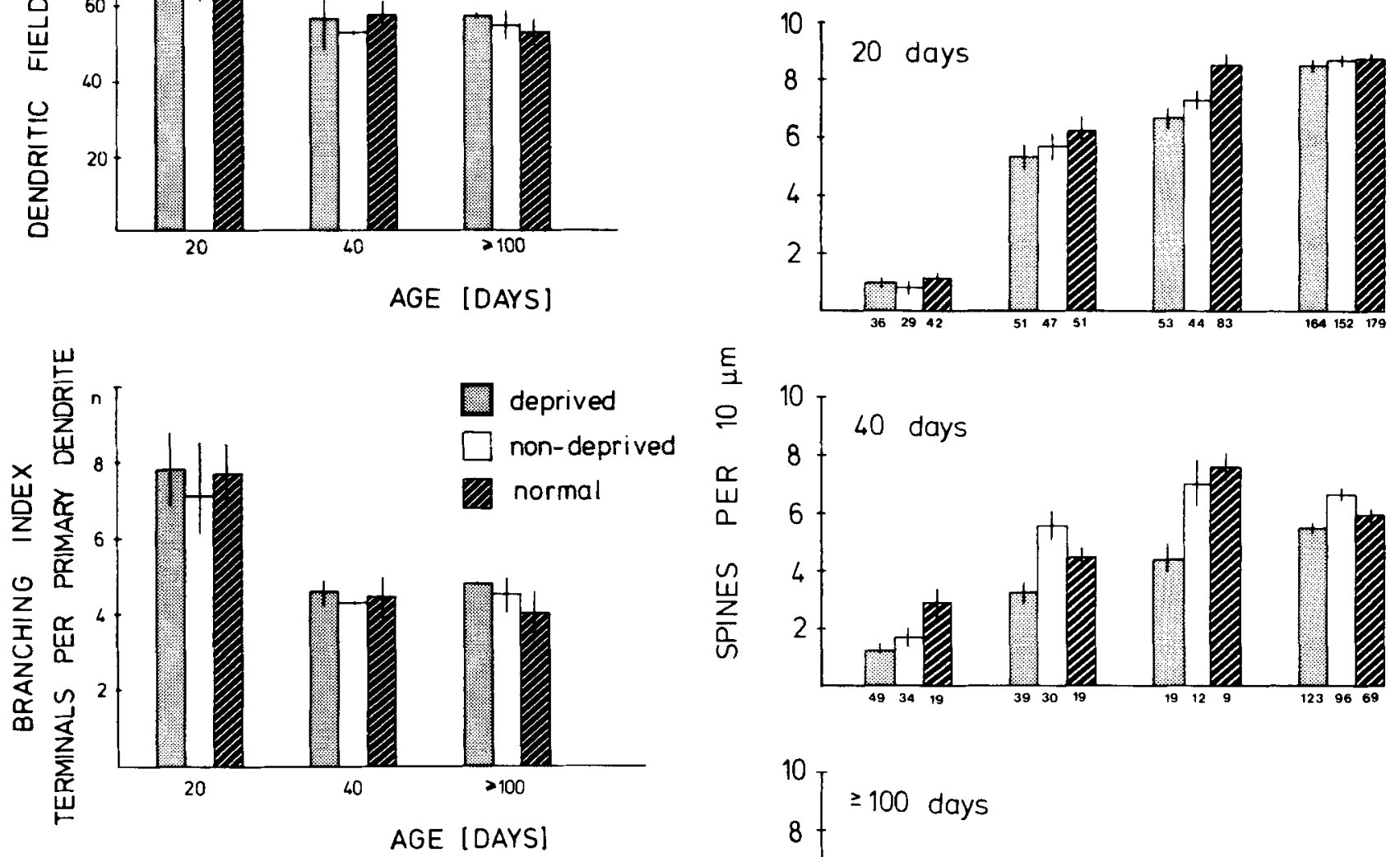

Fig. 9. Effects of various times (20, $40, \geqslant 100$ days) of monocular deprivation on dendritic field radius \pm S.E. (upper) and branchin index + S.E. (bottom) of ectostriatal type I neurons. White columns: nondeprived hemisphere; the shaded columns: deprived hamisphere; hatched columns: normally reared birds. Monocular deprivation has no major effect on both parameters.

\section{Dendritic spines}

Figure 10 shows the median and standard deviation in the spine density of monocularly deprived and normally reared zebra finches at the age of 20,40 , and at least 100 days (see Table 4).

After 20 days of monocular deprivation spine densities of primary dendritic segments of deprived, nondeprived, and normal ectostriatal neurons do not differ significantly. The number of protrusions on secondary dendrites is almost the same in both hemispheres and the value obtained from normally reared zebra finches is not significant $(P>.1)$, even though there is a difference of $14.5 \%$. A similar situation is found in the middle segments, normally reared birds bearing $21.5 \%$ and $14.2 \%$ more spines than both the deprived $(\mathrm{Z}=3.16, P<.005)$ and the nondeprived hemisphere, respectively $(\mathrm{Z}=1.89, P<.095)$. In contrast, terminal dendritic segments are not affected by 20 days of monocular deprivation.

After 40 days of monocular deprivation no interhemispheric difference can be observed on primary dendrites. However, the comparison with the number of spines of
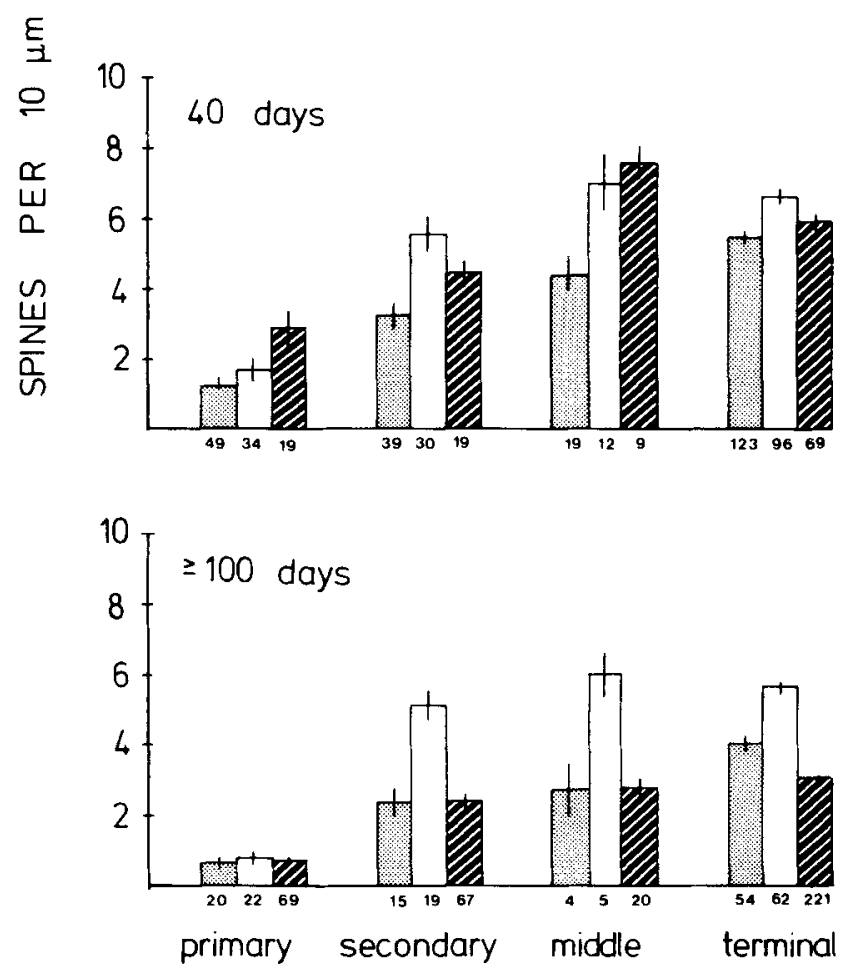

Fig. 10. Number of dendritic spines (median value \pm S.E.) in ectostriatal type I neurons of zebra finches deprived from birth until day 20 (upper), 40 (middle), and $\geqslant 100$ (bottom) in primary, secondary, middle, and terminal dendritic segments. White columns: nondeprived hemisphere; the shaded columns: deprived hemisphere; hatched columns: normally reared birds. The small numbers under the columns show the number of dendritic segments from which the counts were made.

normally reared birds shows a significant reduction in spine density in the deprived $(Z=2.69, P<.01)$ hemisphere. In all other dendritic segments 40 days of unilateral lid closure leads to a clear interhemispheric asymmetry in spine density: neurons in the deprived hemisphere bear a significantly smaller number of spines than neurons in the nondeprived hemisphere (secondary segments: $42.5 \%, \mathrm{Z}=3.28$, $P<.05$, middle segments: $37.8 \%, \mathrm{Z}=2.56, P<.05$, terminal segments: $17.5 \%, \mathrm{Z}=4.04, P<.001$ ). The comparison with normally reared birds is not quite as clear: whereas in secondary and terminal segments the "normal" 
TABLE 3. Dendritic Field Radius (a.) and Branching Index (b.) \pm S.E. in the Deprived and Nondeprived Hemisphere of Zebra Finches, Deprived From Birth Until Day 20,40 , or 100 ( $n=$ number of neurons)

\begin{tabular}{|c|c|c|c|c|c|c|c|c|}
\hline \multirow[b]{2}{*}{ Age } & \multicolumn{4}{|c|}{ a. Dendritic field radius $(\mu \mathrm{m})$} & \multicolumn{4}{|c|}{ b. Branching index } \\
\hline & Deprived & $\mathrm{n}$ & Non-depr. & $\mathrm{n}$ & Deprived & $\mathrm{n}$ & Non-depr. & $\mathrm{n}$ \\
\hline 20 & $69.20 \pm 4.59$ & 36 & $65.68 \pm 4.85$ & 48 & $7.79 \pm 1.02$ & 34 & $7.17 \pm 1.49$ & 36 \\
\hline 40 & $56.59 \pm 8.14$ & 42 & $52.71 \pm 0.16$ & 26 & $4.57 \pm 0.29$ & 34 & $4.28 \pm 0.06$ & 25 \\
\hline$\geqslant 100$ & $57.21 \pm 0.18$ & 19 & $54.40 \pm 3.98$ & 25 & $4.81 \pm 0.04$ & 19 & $4.50 \pm 0.46$ & 23 \\
\hline
\end{tabular}

TABLE 4. Number of Spines (median \pm S.E.) in the Deprived and Nondeprived Hemisphere of Birds Deprived for 20,40 , or $\geqslant 100$ days ${ }^{1}$

\begin{tabular}{|c|c|c|c|c|c|c|c|}
\hline & Age (days) & Deprived & $\mathrm{n}$ & $\begin{array}{c}\text { Non- } \\
\text { Deprived }\end{array}$ & $\mathrm{n}$ & $\%$ diff. & $P$ \\
\hline \multirow{3}{*}{ Primary } & 20 & $0.97 \pm 0.99$ & 36 & $0.81 \pm 1.37$ & 29 & 19.75 & ns \\
\hline & 40 & $1.26 \pm 1.63$ & 49 & $1.73 \pm 1.91$ & 34 & 27.17 & ns \\
\hline & $\geqslant 100$ & $0.65 \pm 0.92$ & 20 & $0.78 \pm 1.09$ & 22 & 16.17 & $\mathrm{~ns}$ \\
\hline \multirow{3}{*}{ Secondary } & 20 & $5.32+3.14$ & 51 & $5.66 \pm 3.38$ & 47 & 6.01 & $\mathrm{~ns}$ \\
\hline & 40 & $3.26 \pm 2.47$ & 39 & $5.67 \pm 3.36$ & 30 & 42.50 & 0.005 \\
\hline & $\geqslant 100$ & $2.36 \pm 1.62$ & 15 & $5.14 \pm 1.87$ & 19 & 54.09 & 0.001 \\
\hline \multirow[t]{3}{*}{ Middle } & 20 & $6.65 \pm 2.61$ & 53 & $7.26 \pm 2.45$ & 44 & 8.40 & $\mathrm{~ns}$ \\
\hline & 40 & $4.34 \pm 2.34$ & 19 & $6.98 \pm 2.85$ & 12 & 37.82 & 0.025 \\
\hline & $\geqslant 100$ & $2.72 \pm 1.77$ & 4 & $6.11 \pm 1.03$ & 2 & 54.36 & 0.05 \\
\hline \multirow[t]{3}{*}{ Terminal } & 20 & $8.43 \pm 2.67$ & 164 & $8.60 \pm 2.90$ & 152 & 1.98 & ns \\
\hline & 40 & $5.45 \pm 2.22$ & 123 & $6.61 \pm 1.85$ & 96 & 17.55 & 0.001 \\
\hline & $\geqslant 100$ & $4.00 \pm 1.42$ & 54 & $5.64 \pm 1.84$ & 62 & 29.08 & 0.001 \\
\hline
\end{tabular}

$1_{n}=$ number of segments; $\%$ diff. = percental difference between deprived and nondeprived hemisphere: $P=$ level of significance.

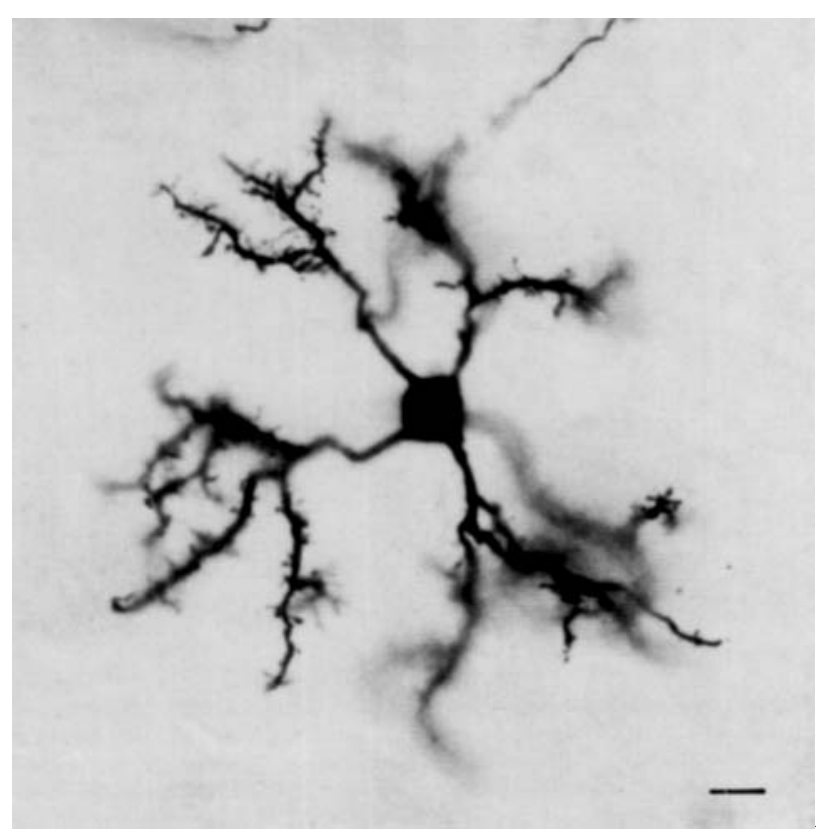

Fig. 11. Type I neuron in the deprived ecostriatum of a 20-day-old deprived zebra finch. The number of dendritic spines, dendritic field radius, and branching index are not significantly affected by monocular deprivation (except the number of spines on middle dendritic segments; see Results). Not all the dendrites and spines are in focus. Bar is $10 \mu \mathrm{m}$.

values lie between those of the deprived and nondeprived hemisphere, the spine density in middle segments in normally reared zebra finches does not differ significantly from that found in the nondeprived hemisphere.

Extending the deprivation period until adulthood $(<100$ days) does not cause further changes concerning the left/ right asymmetries in deprived birds: with exception of the primary dendritic segments, neurons in the deprived hemisphere bear significantly fewer spines than neurons in the corresponding nondeprived hemisphere. The differences are $54 \%$ for secondary $(\mathrm{Z}=3.68, P<.001)$ and middle seg. ments $(\mathrm{Z}=2.20, P<.005)$, and $29 \%$ for terminal dendritic segments $(\mathrm{Z}=4.78, P<.001)$. However, these interhemispheric differences do not result from a reduction in spine density in the deprived hemisphere but rather from an excess of spines in the nondeprived hemisphere, because the spine density of normally reared birds is almost exactly the same as in the deprived hemisphere of zebra finches monocularly deprived until adulthood. In the nondeprived hemisphere there are $115 \%$ more spines on the secondary ( $\mathrm{Z}=4.92, P<.001), 120 \%$ more on the middle $(\mathrm{Z}=3.26, P$ $<.005$ ), and $82 \%$ more on the terminal dendritic segments ( $\mathrm{Z}=8.85, P<.001$ ) compared with normally reared birds. These results show that a period of at least 40 days of monocular deprivation leads to clear changes in spine density of ectostriatal neurons. However, the asymmetries are mainly due to a lack of normally occurring spine reduction in the nondeprived hemisphere rather than to a reduction of protrusions in the deprived hemisphere.

\section{DISCUSSION}

In spite of some problems concerning the completeness, selectivity, and predictability of the impregnation, the Golgi method provides an excellent tool for studying the morphology and ontogeny of dendritic processes. As combined Golgi, EM, or HRP studies have confirmed earlier results based solely on Golgi material, the criticism concerning the reliability and capriciousness of the Golgi method does not seem to be justified (e.g., Caceres and Steward, '83; Greenough, '84; Mates and Lund ' $83 a$,b; but see Feldman and Peters, '79).

This is the first study to follow the development of neurons in a primary visual nucleus of the bird's brain, the ectostriatum. Furthermore, these data show that monocular deprivation dramatically interferes with spine develop- 
ment in this forebrain area. The analysis of the Golgi material of the zebra finch also confirms the findings of Watanabe et al. ('85) in the ectostriatum of quails, who also reported only one main neuron type in this telencephalic region.

Three points deserve further discussion: first, the fact that in such a huge brain area like the ectostriatum there is only one main neuron type; second, the finding that all three parameters studied here exhibit the same developmental trend-namely, an increase from day 5 until day 20 and a subsequent reduction; and third, the result that monocular deprivation seems to have major influences on spine density in the nondeprived hemisphere, i.e., the brain-side driven mainly by the open eye.

\section{Neuron types in the ectostriatum}

Our Golgi material clearly demonstrates only one major neuron type in the ectostriatum of zebra finches. This result is in close agreement with the study of Watanabe et al. ('85) on the quail ectostriatum. Thus, the ectostriatum seems to lack all "typical" telencephalic neurons found in the "visual wulst" (Watanabe et al., '83), the hyperstriatum ventrale, pars caudale $(\mathrm{HVc})$ (Rausch and Scheich, '82), the nucleus robustus archistriatalis (RA) (Katz and Gurney, '81), the medial part of the neostriatum and hyperstriatum (MNH) (Wallhäusser and Scheich, '87), and the hippocampus (Molla et al., '86). In addition, we found a few neurons of a second type with a large cell body and eight to 12 primary dendrites. The comparison of its enormous size of more than $300 \mu \mathrm{m}^{2}$ with size-frequency histograms from Nissl material indicates that it is in fact a rare neuron type. It seems remarkable that such an important primary visual area consists only of two different neuron types, whereby one is absolutely dominant. At present, we do not know whether the main neuron type really represents one homogeneous population. Recent immunohistochemical studies of Braun et al. ('85) and Braun et al. ('87) suggest that this is probably not the case: both papers demonstrate small fractions of parvalbumin- and GABA-positive neurons throughout the ectostriatum.

\section{Development with "overshoot"}

It is now widely accepted that early neuronal development is not only characterized by proliferative but also by regressive phenomena. The data supporting this view come from a variety of developmental studies on both mammals and birds showing a quick rise in neuronal elements such as dendrites (Duffy and Rakic, '83; Furber, '84; Leuba and Garey, '84; Smith, '81; Vaughn, '77), spines (Apfelbach, '86; Apfelbach and Weiler, '85; Boothe et al., '79; Dardennes et al., '84; Duffy and Rakic, '83; Garey and Saini, '81; Murphy, '84; Rakic et al., '86; Rausch and Scheich, '82), synapses (Bähr and Wolff, '85; Cragg, '75; Holstein et al., '85; Purves and Lichtman, '80; Winfield, '83), somata (Cowan, '73; Herrmann and Bischof, '86a; Rager and Rager, '76), or volume (Bottjer et al., '85; Fritschy and Garey, '86; Herrmann and Bischof, ' 86 a) followed by a subsequent reduction in number and/or size.

The quantitative data of the present Golgi study in the zebra finch are in close agreement with the above-mentioned developmental trend in clearly demonstrating a rapid increase in dendritic field radius, branching index, and spine density from birth until day 20 followed by a subsequent overshoot of synaptic connections at day 20 , as longer (dendritic field radius) and more numerous (branching index) dendrites allow contacts to more numerous and more distant neurons, and excess of spines most likely stands for more synapses.

The spine counts should be interpreted with care, as the morphology of the dendritic spines changes, and one cannot exclude the possibility that the counts reflect different populations. However, an EM study from our lab (Nixdorf and Bischof, in preparation) clearly demonstrates that the excess of spines calculated in the present Golgi study is paralleled by an "overshoot" of axospineous synapses at day 20 , so it can be taken for granted that the ectostriatum not only forms but also loses spines during the early postnatal period.

The reduction of dendrites and spines might correlate with decreasing plasticity due to an elimination of nonfunctional synapses. The theoretical work of Changeux and co-workers (e.g., Changeux and Danchin, '76) provides evidence for the functional significance of such developmental trends involving a transient overabundance of synaptic con. nections and subsequent reduction processes. According to his hypothesis, the overshoot of synapses provides the condition under which a selection process can eliminate those connections that fail to function and stabilize functional synapses.

While such a model fits well with ontogenetic studies of the visual cortex of cats and monkeys, where the loss of spines might correlate with the retraction of geniculocortical afferents (e.g., Boothe et al., '79; Le Vay et al., '78, '80; Shatz and Stryker, '78) or the nerve-muscle synapse (Changeux and Danchin, '76), competitive processes have not been demonstrated directly in the ectostriatum of birds so far, and future research should address this issue. Although the ectostriatum has been long believed to be monocularly driven, recent anatomical and physiological evidence from our lab suggests there are binocular interactions in the zebra finch ectostriatum (Engelage and Bischof, ' 88 ; Niemann et al., '87). Interestingly, another parallel can be drawn between the development of the visual system in both cats and zebra finches: the loss of spines or axospinous synapses coincides with the end of the sensitive period for monocular deprivation (Herrmann and Bischof, '88; Winfield, '83). According to Murphy ('84), however, the peak in spine or synapse density coincides with the peak sensibility. Therefore we do not know whether the parallel between these results and those of Winfield ('83) is causal or merely coincidental.

\section{Effects of monocular deprivation}

Several publications have documented dendritic parameters such as dendritic field radius, branching index, and spine density showing plastic changes after deafferentation (e.g., Caceres and Steward, '83; Deitsch and Rubel, '84; Jones and Thomas, '62; Valverde, '68) or early environmental manipulations. De Voogd and Nottebohm ('81) also reported sex differences in dendritic morphology of a song control nucleus in canaries. Whereas rearing conditions (e.g., "enriched" or "impoverished" environment) or electric stimulation has effects on both dendritic length (Fiala et al., '78; Juraska et al., '80; Rutlege et al., '74) and branching index (Conner et al., '82; Fiala et al., '78; Holloway, '66; Rutlege et al., '74; Volkmar and Greenough, '72), these parameters are not significantly affected by dark rearing (Borges and Berry, '78; Coleman and Riesen, '68). The present data on deprived zebra finches also support the view that unilateral lid closure does not lead to abnormalities in dendritic field radius or branching frequency. 
In contrast, visual deprivation clearly interferes with spine development in both mammals and birds. Often experience- or activity-dependent phenomena are accompanied by changes in synaptic density or shape (Apfelbach, '86; Coss and Globus, '79; Globus et al., '73; Koch and Poggio, '83; Miller et al., '85; Riccio and Mathews, '85a,b; Turner and Greenough, '85; Wallhäusser and Scheich, '87). Dark rearing-a special kind of "impoverished" environment-has been reported to lead to a reduction in the number of spines of cortical neurons in both the rat (Winckelmann et al., '76) and the mouse (Ruiz-Marcos and Valverde, '69; Valverde, '67). This result was challenged by Freire ('78), who reexamined Valverde's ('67) result in an EM study and reported not a reduction in spine density but rather a retardation in growth. On the basis of this evidence the difference in the number of spines observed between control and dark-reared animals in the Golgi material of Valverde can be explained easily, since many spines were smaller than the resolution limit of the light microscope. The absence of effects of dark rearing on spine density was also confirmed by Bradley and Horn ('79) in the chicken and by Globus and Scheibel ('67) in the rabbit; the latter authors documented morphological deformations as a result of deprivation.

The effects of monocular deprivation on spine density, however, seem to be similar in the two species tested so far (zebra finch and rat). The two Golgi studies on unilaterally deprived rats (Fifkova, '68; Rothblat and Schwarz, '80) both report a reduction in the number of pyramidal dendritic spines in the visual cortex contralateral to the deprived eye, a result which was confirmed in an EM study by Fifkova ('70). Therefore, in contrast to dark rearing, monocular deprivation seems to lead a reduction in both number (Fifkova, '68; Rothblat and Schwarz, '79) and size of spines (Tiemann, ' 84 , for cats).

The present data indicate that monocular deprivation for at least the first 40 days of life creates significant changes in spine density: neurons in the deprived hemisphere bear significantly fewer spines than those in the corresponding nondeprived hemisphere. This result is in close agreement with the above-mentioned Golgi studies if Fifkova ('68) and Rothblat and Schwarz ('79). A deprivation period of only 20 days is too short a time to induce left/right asymmetries in spine density in the zebra finch. As some premature results from EM material in our lab (Nixdorf and Bischof, in preparation) indicate no left-right asymmetries in dendritic spine size following monocular deprivation, it seems unlikely that a size effect could account for the numeric difference in spine density similar to the above-mentioned effects of dark rearing (Freire, '78; Valverde, '67).

The comparison of the quantitative spine data of deprived $(\geqslant 100$ days) and normally reared birds, however, clearly demonstrates that the spine density is not lower in the deprived hemisphere but rather is higher in the nondeprived brain side. This excess of protrusions after long-term deprivation can be interpreted as a failure to reduce the number of spines found in normally reared zebra finches after day 20 . In contrast, the reduction process of dendritic spines in the deprived hemisphere seems to be accelerated, as in the 40-day-old birds the spine density is already lower than in normally reared birds of the same age (although not significantly in all dendritic segments).

Because of the lack of data from normal, undeprived rats no interspecific comparison can be made. It is not known for mammals whether the left/right asymmetry in spine density is also caused by maintaining connections on the nondeprived hemisphere, although the cell size data in the LGN of the cat (e.g., Hickey et al., '77) and monkey (Headon et al., ' 85 ) could be interpreted in this way. The Golgi data of the present study parallel earlier results on soma size changes (Herrmann and Bischof, ' $86 \mathrm{~b}, \mathrm{c}, \mathrm{d}$ ) in both the ectostriatum and the nucleus rotundus of zebra finches, where we also presented evidence for the main deprivation effects to be on the nondeprived hemisphere.

We can only speculate on the functional significance of these results. However, the increase and subsequent reduction in spine density of the normally reared birds might be explained by learning specialization, as mentioned previously. In monocularly deprived birds the enhanced spine loss (seen at day 40) in the deprived hemisphere might be due to a lack of functional verification resulting from the deprived visual input. The problem then becomes one of explaining why the number of spines does not continue to decrease after 40 days of age. Perhaps this can be explained by interhemispheric connections, such as the tectotectal, tetocontralateral-rotundus, or wulst-ectostriatal projection (Bagnoli et al., '80; Benowitz and Karten, '76; Hunt and Künzle, '76, Niemann et al., '87; Ritchie and Cohen, '77). These projections could participate in the transfer of infor mation from the nondeprived eye to the deprived hemisphere and in this way maintain the normal spine density.

In the nondeprived hemisphere there is considerably less spine reduction. This might reflect the longer susceptibility of the neuronal system to environmental changes, so that the nervous system, remains open to learning should a suitable experience arise. Another interpretation might be that the amount of the processed stimuli positively correlates with the number of spines. It could be argued that the nondeprived hemisphere has to perform twice as much after the elimination of the contralateral deprived hemisphere and therefore retains more spines. A positive correlation between the complexity of the stimuli and the spine density is often claimed in studies involving different rearing conditions (e.g., Renner and Rosenzweig, '87). More recently, Wallhäusser and Scheich ('87) proposed this argument in connection with chickens imprinted on different stimuli.

The two hypotheses might not be mutually exclusive but rather the cause and consequence of the same process. The present results do not distinguish between the two hypotheses, but experiments are in progress in our laboratory.

\section{ACKNOWLEDGMENTS}

We would like to thank Mrs. E. Geissler for the photographs and Mr. R. Church and Dr. N. Clayton for improving the English manuscript. Our thanks are also due to Dr. K. Harris for helpful comments on the manuscript. This work was supported by the Deutsche Forschungsgemeinschaft (Bi 245/4) and a grant from the Minister für Wissenschaft und Forschung des Landes Nordrhein-Westfalen.

\section{LITERATURE CITED}

Apfelbach, R. (1986) Imprinting on prey in ferrets (Mustela putorius F. Furo $L$ ) and its neural correlates. Behav. Processes 12:363-381.

Apfelbach, R., and E. Weiler (1985) Olfactory deprivation enhances normal spine loss in the olfactory bulb of developing ferrets. Neurosci. Lett. 62:169-173.

Bähr, S., and J.R. Wolff (1985) Postnatal development of axosomatic synapses in the rat visual cortex: Morphogenesis and quantitative evalua tion. J. Comp. Neurol. 233:405-420.

Bagnoli P., W. Francesconi, and F. Magni (1977) Visual wulst influences on the tectum opticum of the pigeon. Brain Behav. Evol. 14:217-237. 
Bagnoli, P., A. Burkhalter, A. Visher, H. Henke, and M. Cuenod (1982) Effects of monocular deprivation in choline acetyltransferase and glutamic acid decarboxylase in the pigeon visual wulst. Brain Res. 247:289302.

Bagnoli, P., R. Barselotti, M. Pellegrini, and R. Alesci (1983) Norepinephrine levels in developing pigeon brain: Effect of monocular deprivation on the wulst noradrenergic system. Dev. Brain Res. 10:243-250.

Bagnoli, P., S. Grassi, and F. Magni (1980) A direct connection between the visual wulst and the tectum opticum in the pigeon (Columbia livia) demonstrated by horseradish peroxidase. Arch. Ital. Biol. 118:72-88.

Benowitz, L., and H.J. Karten (1976) Organization of the tectofugal pathway in the pigeon: A retrograde transport study. J. Comp. Neurol. 167:503520.

Blakemore, C. (1978) Maturation and modification in the developing visual system. In R. Heid, H.W. Leibowitz, and H.L. Teuber (eds): Perception. Handbook of Sensory Physiology, Vol. VIII. Heidelberg: Springer, pp. $377-426$.

Boothe, R.G., W.T. Greenough, J.S. Lund, and K. Wrege (1979) A quantitative investigation of spine and dendrite development of neurons in the visual cortex (area 17) of Macaca nemestrina monkeys. J. Comp. Neurol. 186:473-490.

Borges, S., and M. Berry (1978) The effects of dark-rearing on the development of the visual cortex of the rat. J. Comp. Neurol. 180:277-300.

Bottjer, S.W., S.I. Glaessner, and A.P. Arnold (1985) Ontogeny of brain nuclei controlling song learning and behavior in zebra finches. J. Neurosci. 5:1556-1562.

Bradley, P., and G. Horn (1979) Neuronal plasticity in the chick brain: Morphological effects of visual experience on neurones in hyperstriatum accessorium. Brain Res. 162:148-153,

Braun, K., H. Scheich, M. Schachner, and C.W. Heizmann (1985) Cytochrome oxidase activity, and ${ }^{14} \mathrm{C}$ deoxyglucose uptake in the brain of the zebra finch. II. Visual system. Cell Tissue Res. 240:117-127.

Braun, S., H. Scheich, and C. Matute (1987) GABA-Immunhistochemie in einem prägungsrelevanten Vorderhirngebiet beim Haushuhnküken. In N. Elsner and O. Creutzfeldt (eds): New Frontiers in Brain Research. New York: Georg Thieme Verlag, p. 121.

Burkhalter, A., P. Streit, P. Bagnoli, A. Visher, H. Henke, and M. Cuenod (1982) Deprivation induced functional modification in the pigeon visual system. In C. Ajmone Marsand and H. Mathies (eds.): Neuronal Plasticity and Memory Formation, New York: Raven Press, pp. 477-485.

Caceres, A., and O. Steward (1983) Dendritic reorganization in the denervated dentate gyrus of the rat following entorhinal cortical lesions: A Golgi and electron microscopic analysis. J. Comp. Neurol. 214:387-403.

Casagrande, V.A., and R. Joseph (1980) Morphological effects of monocular deprivation and recovery in the dorsal lateral geniculate nucleus in Galago. J. Comp. Neurol. 194:413-416.

Changeux, J.P., and A. Danchin (1976) Selective stabilization of developing synapses as a mechanism for the specification of neuronal networks. Nature 264:705-712

Chow, K.L., and P.D. Spear (1974) Morphological and functional effects of visual deprivation on the rabbit visual system. Exp. Neurol. 42:429 447.

Coleman, P.D., and A.H. Riesen (1968) Environmental effects on cortical dendritic fields. I. Rearing in the dark. J. Anat. 102:363-374.

Connor, J.R., S.E. Beban, J. Melone, A. Yuen, and M.C. Diamond (1982) A quantitative Golgi study in the occipital cortex of the pyramidal dendritic topology of old rats from social isolated environments. Brain Res. $251: 39-44$.

Coss, R.G., and A. Globus (1979) Social experience affects the development of dendritic spines and branches on tectal interneurons in jewel fish. Dev. Psychobiol. 12:347-358.

Cowan, W.M. (1973) Neuronal death as a regulative mechanism in the control of cell number in the nervous system. In M. Rockstein (ed) Development and Aging in the Nervous System. New York: Academic Press, pp. 19-41.

Cragg, B. (1975a) The development of synapses in kitten visual cortex during visual deprivation. Exp. Neurol, 46:445-451.

Cragg, B. (1975b) The development of synapses in the visual system of the cat. J. Comp. Neurol, 160:147-166

Dardennes, R., P.H. Jarreau, and V. Meininger (1984) A quantitative Golgi analysis of the postnatal maturation of dendrites in the central nucleus of the inferior colliculus of the rat. Dev. Brain Res. 16:159-169.

Deitsch, J.S., and E.W. Rubel (1984) Afferent influences on brain stem auditory nuclei of the chicken: Time course and specificity of dendritic atrophy following deafferentation. J. Comp. Neurol. 229:66-79.
De Voogd, T.J., and F. Nottebohm (1981) Sex differences in dendritic morphology of a song control nucleus in the canary: A quantitative Golgi study. J. Comp. Neurol, 196:309-316.

Duffy, C.J., and P. Rakic (1983) Differentiation of granule cell dendrites in the dentate gyrus of the rhesus monkey: A quantitative Golgi study. J. Comp. Neurol. 214:224-237.

Engelage, J., and H.-J. Bischof (1988). Enucleation enhances ipsilateral flash evoked responses in the ectostriatum of the zebra finch (Taeniopygia guttata castanotis Gould). Exp. Brain Res. 70:79-89.

Feldmann, M.L., and A. Peters (1979) A technique for estimating total spine numbers on Golgi-impregnated dendrites. J. Comp. Neurol. 188:527542.

Fiala, B.A., J.N. Joyce, and W.T. Greenough (1978) Environmental complex. ity modulates growth of granule cell dendrites in developing but not in adult hippocampus of rats. Exp. Neurol. 59:372-383.

Fifkova, E. (1968) Changes in the visual cortex of rats after unilateral deprivation. Nature 220:379-381.

Fifkova, E. (1970) The effects of monocular deprivation on the synaptic contacts of the visual cortex. J. Neurobiol. 1:285-294

Fregnac, Y., and M. Imbert (1984) Development of neuronal selectivity in primary visual cortex of cat. Physiol. Rev. 64:325-434.

Freire, M. (1978) Effects of dark-rearing on dendritic spines in layer IV of the mouse visual cortex. A quantitative electron microscopical study. J. Anat. 126:193-201.

Fritschy, J.M., and L.J. Garey (1986) Quantitative changes in morphological parameters in the developing visual cortex of the marmoset monkey. Dev. Brain Res. 29:173-188.

Furber, S.E. (1984) A Golgi study of the development of the inferior olivary nuclear complex in the chicken. J. Comp. Neurol. 225:244-258.

Garey, L.J., and K.D. Saini (1981) Golgi studies of the normal development of neurons in the lateral geniculate nucleus of the monkey. Exp. Brain Res. 44:117-128.

Garey, L.J., and J.D. Pettigrew (1974) Ultrastructural changes in kitten visual cortex after environmental modification. Brain Res. 66:165-172.

Globus, A., M.R. Rosenzweig, E.L. Bennett, and M.C. Diamond (1973) Effects of differential experience on dendritic spine counts in rat cerebellar cortex. J. Comp. Physiol. Psychol. 82:175-181.

Globus, A., and A. Scheibel (1967) The effect of visual deprivation on cortical neurons: A Golgi study. Exp. Neurol. 19:331-345.

Greenough, W.T. (1984) Structural correlates of information storage in the mammalian brain: A review and hypothesis. TINS 7:229-233.

Guillery, R.W. (1972) Binocular competition in the control of geniculate cell growth. J. Comp. Neurol. 114:117-127.

Headon, M.P., J.J. Sloper, R.W. Hirons, and T.P.S. Powell (1985) Effect of monocular closure at different ages on deprived and undeprived cells in the primate lateral geniculate nucleus. Dev. Brain Res. 18:57-78.

Herrmann, K., and H.-J. Bischof (1986a) Delayed development of song control nuclei in the zebra finch is related to behavioral development. J. Comp. Neurol. 245:167-175.

Herrmann, K., and H.-J. Bischof (1986b) Effects of monocular deprivation in the nucleus rotundus of zebra finches: A Nissl and deoxyglucose study. Exp. Brain Res. 64:119-126.

Herrmann, K., and H.-J. Bischof (1986c) Monocular deprivation affects neuron size in the ectostriatum of the zebra finch brain. Brain Res. 379:143146.

Herrmann, K., and H.-J. Bischof (1988d) The sensitive period for the morphological effects of monocular deprivation in two nuclei of the tectofugal pathway of zebra finches. Brain Res. 451:43-53.

Hickey, T.L., P.D. Spear, and K.E. Kratz (1977) Quantitative studies of cell size in the cats' dorsal lateral geniculate nucleus following visual deprivation. J. Comp. Neurol. 172:265-282.

Holloway, R.L. (1966) Dendritic branching: Some preliminary results of training and complexity in rat visual cortex. Brain Res. 2:393-396.

Holstein, G.R., T. Pasik, P. Pasik, and J. Hamori (1985) Early postnatal development of the monkey visual system. II. Elimination of retinogeniculate synapses. Dev. Brain Res. 20:15-31.

Hubel, D.H., and T.N. Wiesel (1970) The period of susceptibility to the physiological effects of unilateral eye closure in kittens. J. Physiol. (Lond.) 206:419-436.

Hunt, S.P., and H. Künzle (1976) Observations on the projections and intrinsic organization of the pigeon optic tectum: An autoradiographic study based on anterograde and retrograde axonal and dendritic flow, J. Comp. Neurol. 170:153-172.

Jones, W.H., and D.B. Thomas (1962) Changes in the dendritic organization 
of neurons in the cerebral cortex following deafferentation. J. Anat. (Lond.) 96:375-381.

Juraska, J.M., W.T. Greenough, C. Elliott, K.J. Mack, and R. Berkowitz (1980) Plasticity in adult rat visual cortex: An examination of several cell populations after differential rearing. Behav. Neurol. Biol. 29:157167.

Katz, L.C., and M.E. Gurney (1981) Auditory responses in the zebra finch's motor system for song. Brain Res. 211:192-197.

Koch, C, and T. Poggio (1983) A theoretical analysis of electric properties of spines. Proc. R. Soc. Lond. [Biol.] 218:455-477.

Leuba, G., and L.J. Garey (1984) Development of dendritic patterns in the lateral geniculate nucleus of monkey: A quantitative Golgi study. Dev. Brain Res. 16:285-299.

Le Vay, S., M.P. Stryker, and C.J. Shatz (1978) Ocular dominance columons and their development in layer IV of the cat's visual cortex. J. Comp. Neurol. 179:223-244.

Le Vay, S., T.N. Wiesel, and D.H. Hubel (1980) The development of ocular dominance columns in normal and visually deprived monkeys. J. Comp. Neurol 191:1-51.

Mates, S.L., and J.S. Lund (1983a) Neuronal composition and development in lamina 4C of monkey striate cortex. J. Comp. Neurol. 221:60-90.

Mates, S.L., and J.S. Lund (1983b) Spine formation and maturation of type I synapses on spiny stellate neurons in primate visual cortex. J. Comp. Neurol. 221:91-97.

Miller, J.P., W. Rall, and J. Rinzel (1985) Synaptic amplification by active membrane in dendritic spines. Brain Res. 325:325-330.

Molla, R., J. Rodriguez, S. Calvet, and J.M. Garcia-Verdugo (1986) Neuronal types in the cerebral cortex of the adult chicken (Gallus gallas). I. Hirnforseh. 27:381-390.

Movshon, J.A., and R.C. Van Sluyters (1981) Visual neural development. Annu. Rev. Psychol. 32:477-522.

Murphy, E.H. (1984) Critical periods and the development of the rabbit visual cortex. In J. Stone, B. Dreher, and D.H. Rapaport (eds): Development of Visual Pathways in Mammals. New York: Alan R. Liss, Inc., pp. $429-462$.

Nauta, W.J.H., and H.J. Karten (1970) A general profile of the vetebrate brain with sidelights of an ancestry of the cerebral cortex. In F.O. Schmitt (ed): The Neurosciences Second Study Program. New York: Rockefeller University Press, pp. 7-26.

Niemann, J., J. Engelage, and H.-J. Bischof (1987) Rückkreuzende visuelle Projektionen im tectofugalen System des Zebrafinken (Taeniopygia guttata castanotis). In N. Elsner and O. Creutzfeldt (eds): New Frontiers in Brain Research. Proceedings of the 15th Göttingen Neurobiology. Stuttgart: Georg Thieme Verlag, p. 166.

Nixdorf, B., and H.-J. Bischof (1987) Ultrastructural effects of monocular deprivation in the neuropil of nucleus rotundus in the zebra finch: $A$ quantitative electron microscopic study. Brain Res. 405:326-336.

O'Kusky, d., and M. Colonnier (1982) Postnatal changes in the number of neurons and synapses in the visual cortex (area 17) in the macaque monkey: A stereological analysis in normal and monocularly deprived animals. J. Comp. Neurol. 210:291-306.

Pettigrew, J., and M. Konishi (1976) Effects of monocular deprivation on binocular neurones in the owl's visual wulst. Nature 264:753-754.

Purves, D., and J.W. Lichtman (1980) Elimination of synapses in the developing nervous system. Science 210:153-157.

Rakic, P., J.-P. Bougeois, M.F. Eckenhoff, N. Zecevic, and P.S. Goldman Rakic (1986) Concurrent overproduction of synapses in diverse regions of the primate cerebral cortex. Science 232:232-235.

Rager, G., and U. Rager (1976) Generation and degeneration of retinal ganglion cells in the chicken. Exp. Brain Res. 25:551-553.

Rausch, G., and H. Scheich (1982) Dendritic spine loss and enlargement during maturation of the speech control system in the mynah bird (Gracula religiosa). Neurosci. Lett. 46:131-136.

Renner, M.J., and M.R. Rosenzweig (1987) Enriched and Impoverished Environments. Heidelberg: Springer-Verlag.

Revzin, A.M., and H.J. Karten (1966/67) Rostral projection of the optic tectum and the nucleus rotundus in the pigeon. Brain Res. 3:264-276.

Riccio, R.V., and M.A. Mathews (1985a) The postnatal development of the rat primary visual cortex during optic nerve impulse blockade by intraocular tetrodotoxin: A quantitative electron microscopic analysis. Dev. Brain Res. 20:55-68.

Riccio, R.V., and M.A. Mathews (1985b) Effects of intraocular tetrodotoxin on dendritic spines in the developing rat visual cortex: A Golgi analysis. Dev. Brain Res. 19:173-182.
Ritchie, T.C., and D.H. Cohen (1977) The avian tectofugal visual pathway: Projections of its telencephalon target ectostriatal complex. Soc. Neu rosci. Abs. 3:94.

Romeis, B. (1968) Mikroskopische Technik. Wien: Oldenbourg Verlag.

Rothblat, L.A., and M.L. Schwarz (1979) The effect of monocular deprivation on dendritic spines in the visual cortex of young and adult albino rats: Evidence for a sensitive period. Brain Res. 161:156-161.

Ruiz-Marcos, A., and F. Valverde (1969) The temporal evolution of the distribution of dendritic spines in the visual cortex of normal and darkreared mice. Exp. Brain Res. 8:284-294.

Rutlege, L.T., C. Wright, and J. Duncan (1974) Morphological changes in pyramidal cells of mammalian neocortex associated with increased use. Exp. Neurol. 44:209-228.

Schüz, A. (1981) Pränatale Reifung und postnatale Veränderungen im Cortex des Meerschweinchens: Mikroskopische Auswertung eines natür lichen Deprivationsexperiments. I. Pränatale Reifung. J. Hirnforsch 22:93-111.

Shatz, C.J., and M.P. Stryker (1978) Ocular dominance in layer IV of the cat's visual cortex and the effects of monocular deprivation. J. Physiol. (Lond.) 281:267-283

Sherman, S.M., and P.D. Spear (1982) Organization of visual pathways in normal and visually deprived cats. Physiol. Rev. 62:738-855.

Sherman, S.M., and J.R. Wilson (1975) Behavioral and morphological evidence for binocular competition in the postnatal development of the dog's visual system. J. Comp. Neurol. 161:163-196.

Smith, Z.D.J. (1981) Organization and development of brain stem auditory nuclei in the chicken: Dendritic development in $\mathrm{n}$. laminaris. J. Comp. Neurol. 203:309-333.

Tiemann, S.B. (1984) Effects of monocular deprivation on the geniculocortical synapses in the cat. J. Comp. Neurol. 222:166-176.

Turlejki, K., und M. Kossut (1985) Decrease in the number of synapses formed by sobcortical inputs to the striate cortex of binocularly deprived cats. Brain Res. 331:115-125.

Turner, A.M., and W.T. Greenough (1985) Differential rearing effects on rat visual cortex synapses. I. Synaptic and neuronal density and synapses per neuron. Brain Res. 329:195-203.

Valverde, F. (1967) Apical dendritic spines of the visual cortex and light deprivation in the mouse. Exp. Brain Res. 3:337-352.

Valverde, F. (1968) Structural changes in the area striata of the mouse after enucleation. Exp. Brain Res. 5:274-292.

Vaughan, D.W. (1977) Age related deterioration of pyramidal cell basal dendrites in rat auditory cortex. J. Comp. Neurol. 171:501-516.

Volkmar, F.R., and W.T. Greenough (1972) Rearing complexity affects branching of dendrites in the visual cortex of the rat. Science 176:14451447.

Vrensen, G., and D. de Groot (1975) The effect of monocular deprivation on the synaptic terminals in the visual cortex of rabbits. Brain Res. 93:1524.

Wallhäusser, E., and H. Scheich (1987) Auditory imprinting leads to differ. ential 2-deoxyglucose uptake and dendritic spine loss in the chick rostral forebrain. Dev. Brain Res. 31:29-44.

Watanabe, M., H. Ito, and H. Masai (1983) Cytoarchitecture and visual receptive neurons in the wulst of the japanese quail (Coturnix coturnix japonica). J. Comp. Neurol. 213:188-198.

Watanabe, M., H. Ito, and M. Ikushima (1985) Cytoarchitecture and ultrastructure of the avian ectostriatum: Afferent terminals from the dorsal telencephalon and some nuclei in the thalamus. J. Comp. Neurol. 236:241-257.

Wiesel, T.N., and D.H. Hubel (1963a) Effects of visual deprivation on morphology and physiology of cells in the cat's lateral geniculate body. J. Neurophysiol. 26:978-993.

Wiesel, T.N., and D.H. Hubel (1963b) Single cell responses in striate cortex of kittens deprived of vision in one eye. J. Neurophysiol. 26:1003-1017.

Wiesel, T.N., and D.H. Hubel (1965) Comparison of the effects of unilateral and bilateral closure on cortical unit responses in kittens. J. Neurophysiol. $28: 1029-1040$

Winfield, D.A. (1983) The postnatal development of synapses in different laminae of the visual cortex in the normal kitten and kittens with eyelid suture. Dev. Brain Res. 9:155-169.

Winkelmann, E., K. Brauer, and L. Werner (1976) Untersuchungen zu Spineveränderungen der Lamina V-Pyramidenzellen im visuellen Kortex junger Laborratten nach Dunkelaufzucht und Zerstörung des Corpus geniculatum laterale, pars dorsalis. J. Hirnforsch. 17:489-500. 